of bovine insulin often cross react with human insulin. ${ }^{2}$ The antibodies formed against the $\mathrm{C}$ peptide portion of the bovine proinsulin molecule (present as a contaminant in some preparations of insulin) can, however, be distinguished immunologically and if present provide good evidence of previous administration of bovine insulin. ${ }^{3} \mathrm{~A}$ further advantage of diagnosing factitious hypoglycaemia in this way is that the sample can be taken at any stage and is not dependent on the patient being hypoglycaemic. Proof of exogenous administration, however, becomes more difficult when highly purified pork or human insulin has been administered.

We thank Professor V Marks and Dr D J Teale, St Luke's Hospital, Guildford, and Drs C Gordon and I Laing, Manchester Royal Infirmary, for their help and advice.

1 Marks V, Rose FC. Hypoglycaemia. 2nd ed. Oxford: Blackwell Scientific Publications, 1981

Reeves WG, Kelly $U$. Insulin antibodies induced by bovine insulin therapy. Clin Exp Immunol 1982;50:163-70.

3 Reeves WG, Douglas CA. C-peptide antibodies induced by bovine insulin therapy. Clin Exp Immunol 1982;50:171-7.

Bauman WA, Yalow RS. Differential diagnosis between endogenous and exogenous insulin induced refracto

5 Meistas MT, Kumar MS, Schumacher OP. Diagnosis of self induced hypoinsulinaemia in an insulin dependent diabetic patient by radioimmunoassay of free C-peptide. Clin Chem 1981;27:184-6.

(Accepted 18 fanuary 1985)

Department of Clinical Biochemistry and Medicine, Hope Hospital, Salford M6 8HD

I ROBERTS, MSC, MB, senior registrar

H COHEN, MB, FRCP, consultant physician

Department of Immunology, University Hospital, Queen's Medical Centre, Nottingham NG7 2UH

W G REEVES, MRCS, LRCP, consultant immunologist

Correspondence to: Dr Ian Roberts.

\section{Neurological complications of pulmonary arteriovenous malformations}

Pulmonary arteriovenous fistulas are uncommon congenital lesions, which sometimes form part of the syndrome of hereditary haemorrhagic telangiectasia. I report two cases that illustrate some of the clinical features of the lesions and, more importantly, highlight the rarely recognised association with neurological problems. ${ }^{1}$

\section{Case 1}

A previously healthy woman aged 47 presented to her optician suffering from blurred vision and headaches. A defect in the upper temporal field was found in the left eye. The inferior nasal branch of the retinal artery was occluded, but no embolus was seen. Auscultation over the chest elicited a continuous murmur loudest in the right axilla. There was no cyanosis or finger clubbing.

The haemoglobin concentration on presentation was $12.0 \mathrm{~g} / \mathrm{dl}$ (packed cell volume 0.36 ). Routine biochemistry, including plasma lipid and blood glucose concentrations, gave normal results. A radiograph of the chest showed a rounded opacity in the right lower lobe. Tomography and pulmonary angiography confirmed this as a pulmonary arteriovenous fistula. Carotid angiography gave normal results. She underwent resection of the right lower lobe and afterwards suffered no further neurological problems, although the field defect persisted.

\section{Case 2}

A 34 year old man who smoked presented with aphasia and right sided sensory symptoms of sudden onset. These completely resolved within 24 hours. Subsequent examination yielded normal results except for central cyanosis and finger clubbing. No bruit was audible over the chest. Seven years earlier a routine radiograph of the chest had shown a pulmonary arteriovenous fistula, which was confirmed by tomography. No action had been taken. A recent radiograph (figure) had shown two rounded opacities in the right lower lobe, rather larger than before. Pulmonary arteriography showed three fistulas in the right lower and middle lobes.
He was hypoxaemic (oxygen pressure $8.6 \mathrm{kPa}(65 \mathrm{~mm} \mathrm{Hg})$ ) and hypocapnoeic (carbon dioxide pressure $3.4 \mathrm{kPa}(26 \mathrm{~mm} \mathrm{Hg}$ )). This was compatible with a right to left shunt. The haemoglobin concentration was $18.6 \mathrm{~g} / \mathrm{dl}$ (packed cell volume 0.57 ). Routine biochemistry, including plasma lipid and blood glucose concentrations, and echocardiography, computed tomography of the brain, and bilateral carotid angiography produced normal results. He underwent resection of the right middle and lower lobes. Eight months later the blood gas tensions were normal (oxygen pressure $11.6 \mathrm{kPa}$ $(87 \mathrm{~mm} \mathrm{Hg}$ ), carbon dioxide pressure $5.0 \mathrm{kPa}(38 \mathrm{~mm} \mathrm{Hg})$, and the haemoglobin concentration had fallen to $14.9 \mathrm{~g} / \mathrm{dl}$ (packed cell volume 0.47 )). He sustained no further transient ischaemic attacks.

\section{Comment}

Pulmonary arteriovenous fistulas may be associated with exertional dyspnoea, haemoptysis, and chest pain. ${ }^{2}$ Neither patient suffered these symptoms, but cumulatively they illustrate the common physical signs: cyanosis, finger clubbing, and continuous murmur Many patients have neither symptoms (about 38\%) nor signs. ${ }^{2}$

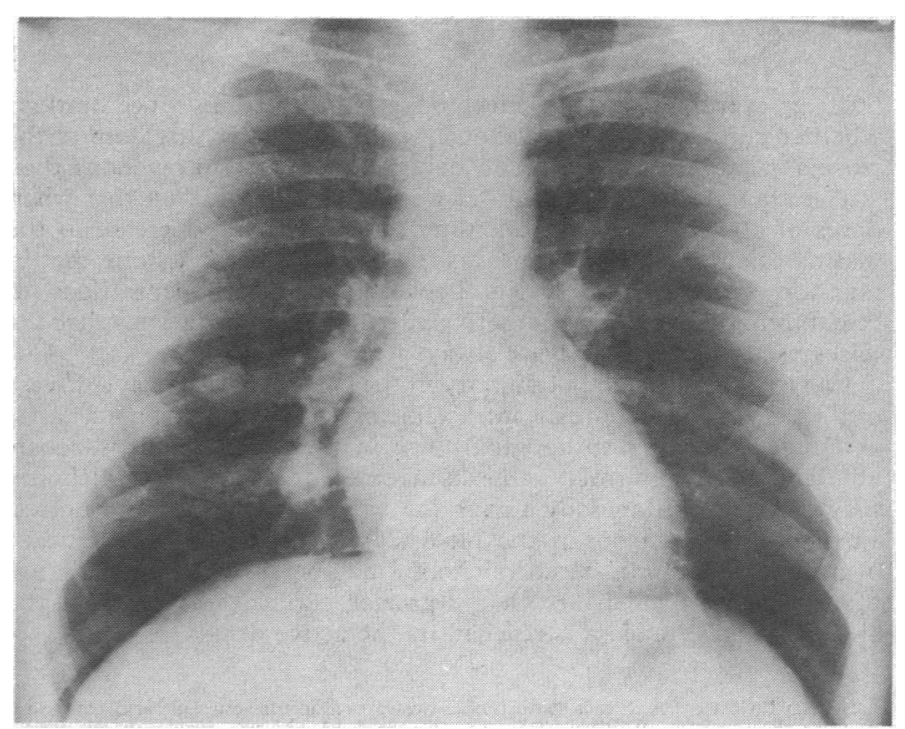

Posteroanterior chest radiograph showing pulmonary arteriovenous malformation (case 2)

Several explanations for these neurological deficits are possible. In case 2 polycythaemia causing increased blood viscosity $(1.31 \mathrm{mPa}$ $(\mathrm{cP})$, normal $1 \cdot 15-1 \cdot 25 \mathrm{mPa} \mathrm{s}$ ) could have resulted in cerebral thrombosis, although the short duration of the deficit might favour an embolic mechanism. ${ }^{34}$ Haemorrhage from associated cerebral arteriovenous malformations has been suggested, but in both cases carotid angiography yielded normal results. Emboli could have arisen from the pulmonary arteriovenous fistulas secondary to turbulent flow, or perhaps from deep veins with "paradoxical embolisation" through the right to left shunt. It is this shunt that accounts for the cyanosis and polycythaemia. Interestingly, in case 2 the polycythaemia was predominantly due to a reduction in plasma volume $(33.7 \mathrm{ml} / \mathrm{kg}$, normal $40-50 \mathrm{ml} / \mathrm{kg}$ ) with little increase in red cell mass $(31.9 \mathrm{ml} / \mathrm{kg}$, normal $25-35 \mathrm{ml} / \mathrm{kg}$ ). This "stress" type polycythaemia is clearly not the usual response to hypoxaemia, although it reversed postoperatively (plasma volume $40.7 \mathrm{ml} / \mathrm{kg}$, red cell mass $26.9 \mathrm{ml} / \mathrm{kg}$ ).

Gomes et al reviewed 47 patients with pulmonary arteriovenous fistulas. ${ }^{2}$ Of 19 treated conservatively, three, aged 45-55, suffered fatal cerebrovascular accidents. They recommended that patients with symptoms, enlarging fistulas, and associated hereditary haemorrhagic telangiectasia should be offered surgery owing to the higher incidence of complications.

We believe that the clinical importance of pulmonary arteriovenous fistulas is widely underestimated. If detected they should be fully investigated and considered for surgical treatment.

I thank Dr P S Monro, Dr F G Campbell, and Mr N L Wright for their permission to report these cases; Dr A G Wilson for interpreting the radiographs; and Helen Gadsby for preparing the manuscript. 
1 Bazelly B, Marchand M, de Riberolles C, et al. Accidents neurologiques a repetition par fistules arterio-veineuses pulmonaires. Nouve Presse Med 1981;10: tion par

2 Gomes MR, Bernatz PE, Dines DE. Pulmonary arterio-venous fistulas. Ann Thorac Surg 1969;7:582-90.

3 Moyer JH, Glantz G, Brest AN. Pulmonary arterio-venous fistulas. Am $\mathcal{F}$ Med $1962 ; 32: 417-35$. 4 Przybojewzki JZ, Maritz F. Pulmonary arterio-venous fistulas. $S$ Afr Med $\mathcal{f}$
1980;57:366-73.

(Accepted 13 February 1985)

Atkinson Morley's Hospital, London SW20 0NE

M S DENNIS, MB, MRCP, senior house officer in neurology

Correspondence to: Dr M S Dennis, 16 St Peter's Court, 93 King's Avenue, London SW4 8EH.

\section{Stress, cortisol concentrations, and lymphocyte subpopulations}

The aetiology of rheumatoid arthritis is almost certainly multifactorial, so that established genetic factors and suspected infective agents do not preclude the possibility of psychological factors also influencing the onset of disease. ${ }^{1}$ This influence may be mediated by stress modifying the responses of the immune system. ${ }^{2}$ Before starting further studies of people with disease we therefore decided to investigate the responses of $\mathrm{T}$ lymphocyte populations in normal students under stress.

\section{Subjects, methods, and results}

We invited medical students on the second day of their clinical course in a medical school new to them to participate in the study. All 35 with surnames beginning $A$ to $G$ were approached: 33 accepted, attending during their first week (October 1983). Twenty eight second year students served as

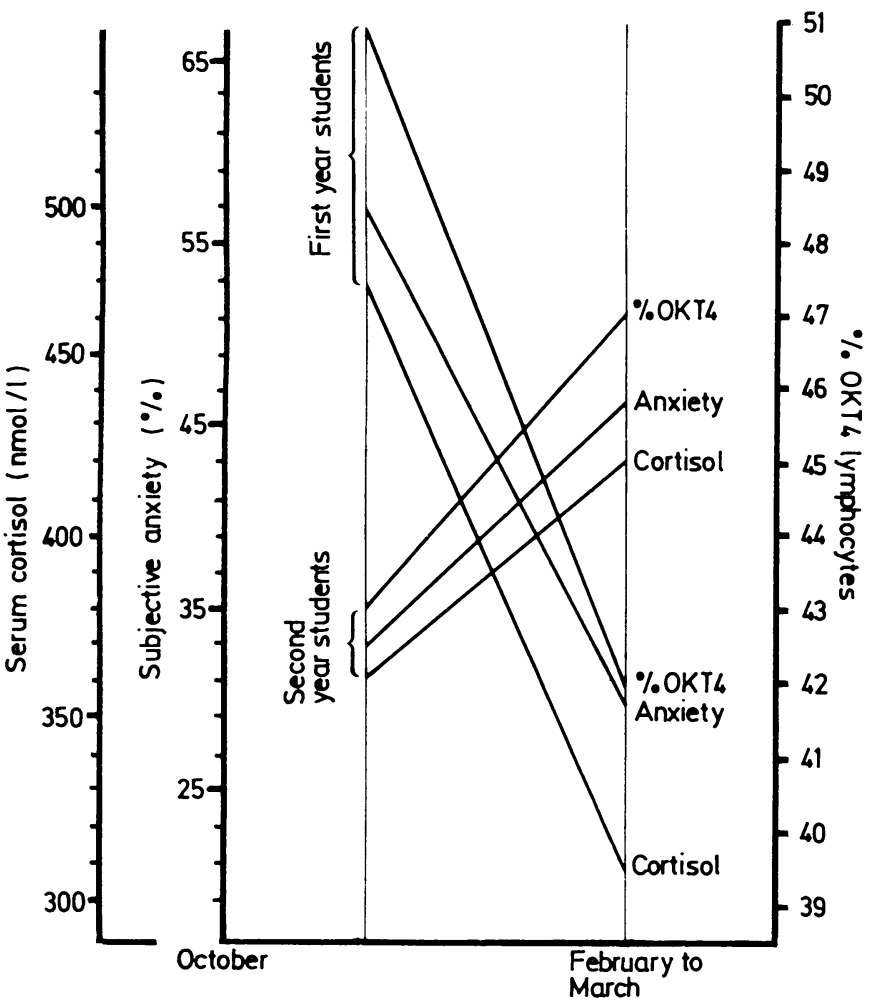

Subjective anxiety scores, serum cortisol concentrations, and proportions of OKT4 lymphocytes in first and second year students.

Conversion: SI to traditional units-Cortisol: $1 \mathrm{nmol} / 1 \approx 0.036 \mu \mathrm{g} / 100 \mathrm{ml}$ controls. Thirty one of the first year students and 22 of the second year students were tested again about four months later (in February and March 1984). Each student assessed his or her subjective anxiety on that day on an uncalibrated $10 \mathrm{~cm}$ visual analogue scale, the extremes of which were marked

"The day of my life I felt least /most anxious or tense." The score was recorded as zero (least) to 100 (most). Personal and family histories of atopic disorder were asked for and no difference was found between first and second year students.

All students were seen between 11 am and $1 \mathrm{pm}$ to avoid the effects of diurnal variation. Total leucocyte and lymphocyte counts were determined using a Coulter S Plus counter. Parallel heparinised blood samples were separated on discontinuous Ficoll-metrizoate (Triosil) gradients, incubated with fluoresceinated monoclonal anti-T cell antibodies (Ortho-Mune OKT series) without the addition of any fetal calf serum, and analysed on the cytofluorograph (FACS 420; Becton Dickinson). ${ }^{3}$ Scatter gates set on the 90 light scatter profile were used to minimise contamination of cell preparations with non-lymphocytic cells. The heparinised plasma was frozen and used to measure serum cortisol concentrations.

At the first testing nine first year students and one second year student did not have lymphocyte subpopulation estimations done, but their anxiety and cortisol measurements were included in the calculation of those means.

The Mann-Whitney test, two tailed, was used to compare the first with the second year students at the first and second visits, while Wilcoxon's matched pairs test, two tailed, was used to compare the first with the second visit of both groups of students.

The figure illustrates the differences in means among the four sets of results (though the means were not used in the statistics). The new students showed significantly higher subjective anxiety scores and cortisol concentrations than the second year students and than themselves at the second visit (all $\mathrm{p}$ values $<0.005$ ). This finding was associated with a significantly raised proportion of OKT 4 cells when compared with the second year students at the same time $(p=0.0001)$ and with themselves a few months later $(\mathrm{p}<0.005)$. The second year students showed increases in anxiety, cortisol values, and proportions of OKT 4 cells at their second visit, probably because they were approaching an examination, but the increases did not reach significance. There were no significant changes in white cell counts, lymphocyte counts, or proportions of OKT8 cells.

\section{Comment}

Students during their first week experienced a high level of psychological and physiological arousal, shown by raised subjective anxiety scores and serum cortisol concentrations. These features were associated with a significant increase in the proportion of OKT4 cells (helper T lymphocytes).

Not all psychological states produce similar responses: for example, Kronfol and House, commenting on our preliminary results, ${ }^{4}$ reported that they had found no difference in the percentage of lymphocyte subsets when comparing depressed people with controls. ${ }^{5}$

Probably our finding is only part of a far more complicated immune response to stress. In many diseases (well represented by rheumatoid arthritis) the influence of stress and other emotional factors on the immune system may prove to be of fundamental importance in both susceptibility to disease and subsequent fluctuations during the course of disease.

Baker GHB, Brewerton DA. Rheumatoid arthritis: a psychiatric assessment. Br Med F 1981;282:2014-6.

Baker GHB. Life events before the onset of rheumatoid arthritis. Psychother

3 Hoffman RA, Kung PC, Hansen WP, Goldstein G. Simple and rapid measurement of human T-lymphocytes and their subclasses in peripheral blood. Proc

4 Baker GHB, Byrom NA, Irani MS, et al. Stress, cortisol, and lymphocyte sub-

populations. Lancet $1984 ; \mathrm{i}: 574$.

Kronfol Z, House JD. Depression, cortisol, and immune function. Lancet 1984; i:1026-7.

(Accepted 30 fanuary 1985)

Charing Cross and Westminster Medical School, London

G H B BAKER, MD, FRCPSYCH, consultant psychiatrist

M S IRANI, BSC, MRCP, senior registrar in rheumatology

N A BYROM, BTECH, PHD, lecturer in chemical immunology

N M NAGVEKAR, BSC, research assistan

R J WOOD, BSC, computer programmer

J R HOBBS, MD, FRCPATH, professor of chemical immunology

D A BREWERTON, MD, FRCP, consultant rheumatologist

Correspondence to: Dr G H B Baker, Department of Rheumatology, Westminster Hospital, London SW1P 2AP. 